\title{
Berberine reduces cAMP-induced chloride secretion in T84 human colonic carcinoma cells through inhibition of basolateral KCNQ1 channels
}

\author{
Rodrigo Alzamora ${ }^{1, \dagger}$, Fiona O'Mahony ${ }^{1, \dagger}$, Wing-Hung Ko ${ }^{2}$, Tiffany Wai-Nga Yip ${ }^{2}$, Derek Carter ${ }^{1}$, \\ Mustapha Irnaten ${ }^{1}$ and Brian Joseph Harvey ${ }^{1 *}$
}

1 Department of Molecular Medicine, Education and Research Centre, Royal College of Surgeons in Ireland, Beaumont Hospital, Dublin, Ireland

${ }^{2}$ Department of Physiology, Faculty of Medicine, The Chinese University of Hong Kong, Shatin, Hong Kong

Edited by:

Ali Mobasheri, The University of

Nottingham, UK

Reviewed by:

Richard Barrett-Jolley, University of Liverpool, UK

Carlos A. Flores, Centro de Estudios

Científicos, Chile

\section{${ }^{*}$ Correspondence}

Brian Joseph Harvey, Department of

Molecular Medicine, Education and

Research Centre, Royal College of

Surgeons in Ireland, Beaumont

Hospital PO Box 9063, Dublin 9,

Ireland.

e-mail: bjpharvey@rcsi.ie

${ }^{\dagger}$ Rodrigo Alzamora and Fiona

O'Mahony have contributed equally

to this work.
Berberine is a plant alkaloid with multiple pharmacological actions, including antidiarrhoeal activity and has been shown to inhibit $\mathrm{Cl}^{-}$secretion in distal colon. The aims of this study were to determine the molecular signaling mechanisms of action of berberine on $\mathrm{Cl}^{-}$secretion and the ion transporter targets. Monolayers of T84 human colonic carcinoma cells grown in permeable supports were placed in Ussing chambers and short-circuit current measured in response to secretagogues and berberine. Whole-cell current recordings were performed in T84 cells using the patch-clamp technique. Berberine decreased forskolininduced short-circuit current in a concentration-dependent manner $\left(\mathrm{IC}_{50} 80 \pm 8 \mu \mathrm{M}\right)$. In apically permeabilized monolayers and whole-cell current recordings, berberine inhibited a cAMP-dependent and chromanol 293B-sensitive basolateral membrane $\mathrm{K}^{+}$current by $88 \%$, suggesting inhibition of $\mathrm{KCNQ} 1 \mathrm{~K}^{+}$channels. Berberine did not affect either apical $\mathrm{Cl}^{-}$conductance or basolateral $\mathrm{Na}^{+}-\mathrm{K}^{+}-$ATPase activity. Berberine stimulated p38 MAPK, PKC $\alpha$ and PKA, but had no effect on p42/p44 MAPK and PKC 8 . However, berberine pre-treatment prevented stimulation of p42/p44 MAPK by epidermal growth factor. The inhibitory effect of berberine on $\mathrm{Cl}^{-}$secretion was partially blocked by HBDDE ( 65\%), an inhibitor of PKC $\alpha$ and to a smaller extent by inhibition of p38 MAPK with SB202190 ( 15\%). Berberine treatment induced an increase in association between PKC $\alpha$ and PKA with KCNQ1 and produced phosphorylation of the channel. We conclude that berberine exerts its inhibitory effect on colonic $\mathrm{Cl}^{-}$secretion through inhibition of basolateral $\mathrm{KCNQ} 1$ channels responsible for $\mathrm{K}^{+}$ recycling via a $\mathrm{PKC} \alpha$-dependent pathway.

Keywords: berberine, KCNO1 $\mathrm{K}^{+}$channels, CFTR, chloride secretion, colon ion transport, T84 cells

\section{INTRODUCTION}

Berberine is a benzodioxoquinolone plant alkaloid isolated from several species of Berberis and Coptis. In Chinese and Hindu medicine, berberine has been used to treat gastroenteritis, abdominal pain, and diarrhea for over two millennia. Various pharmacological actions have been described for berberine, including antimicrobial (Iwasa et al., 1998), anti-inflammatory (Ivanovska and Philipov, 1996), and cardiovascular effects (Lau et al., 2001). In several small-scale clinical trials, berberine has proven effective in the treatment of secretory diarrhea (Rabbani et al., 1987; Tang and Eisenbrand, 1992). Although its therapeutic benefit has been attributed in part to its antimicrobial and antimotility properties (Yamamoto et al., 1993), berberine has been shown to prevent epithelial electrolyte secretion in vitro in rabbit and rat intestine (Guandalini et al., 1987; Taylor and Baird, 1995).

Diarrheal diseases continue to be a major cause of morbidity and mortality in children and elderly people throughout the world. Oral rehydration therapy remains the mainstay of treatment for diarrhea (Taylor and Greenough, 1989). However, in recent years significant effort has been made in the search for antisecretory drugs that will directly inhibit secretory processes within the enterocytes (Ma et al., 2002; Farthing, 2006).

Activated $\mathrm{Cl}^{-}$secretion from the intestinal crypt is thought to play a major role in secretory diarrhea of several aetiologies (Field, 2003). The generation of the electrochemical driving force required for $\mathrm{Cl}^{-}$secretion by crypt epithelial cells depends on their ability to accumulate intracellular $\mathrm{Cl}^{-}$ions to concentrations greater than their electrochemical equilibrium (Barrett and Keely, 2000; Kunzelmann and Mall, 2002). $\mathrm{Cl}^{-}$enters the cell across the basolateral membrane through the activity of $\mathrm{Na}^{+}$ $\mathrm{K}^{+}-2 \mathrm{Cl}^{-}$cotransporters. The cotransporter is, in turn, driven by a strong inwardly directed electrochemical $\mathrm{Na}^{+}$gradient established by the basolaterally located $\mathrm{Na}^{+}-\mathrm{K}^{+}$-ATPase. In order to maintain the membrane potential at rest and during $\mathrm{Cl}^{-}$secretion, both $\mathrm{Na}^{+}$and $\mathrm{K}^{+}$must be recycled out of the cell through the basolateral membrane. The $\mathrm{Na}^{+}-\mathrm{K}^{+}$-ATPase serves to recycle $\mathrm{Na}^{+}$, while basolateral potassium channels recycle $\mathrm{K}^{+}$(Schultheiss and Diener, 1998). The basolateral $\mathrm{K}^{+}$conductance in intestinal epithelial cells is formed by at least two different types of $\mathrm{K}^{+}$ channels, one activated by $\mathrm{Ca}^{2+}$-mobilizing secretagogues and the 
other by cAMP-dependent agonists (Heitzmann and Warth, 2008). Electrophysiological studies have revealed the latter to be KCNQ1, a low conductance (1-3 pS) basolateral $\mathrm{K}^{+}$channel, which is activated during cAMP-stimulated $\mathrm{Cl}^{-}$secretion and inhibited by chromanol 293B and HMR-1556 (Schroeder et al., 2000; Robbins, 2001). As in all secretory epithelia, the channels and transporters of the crypt epithelial cell must operate in concert to achieve vectorial ion transport. Therefore, blockade of specific basolateral $\mathrm{K}^{+}$conductance would be expected to inhibit the $\mathrm{Cl}^{-}$secretory process.

The T84 cell line is a well-differentiated intestinal human carcinoma cell line proved to be a robust model for the study of molecular mechanisms of intestinal secretion in close to 1,200 publications since the early 1980s (Dharmsathaphorn et al., 1984). Previous studies using T84 cells, grown to confluence and mounted in Ussing chambers, have shown that berberine decreased $\mathrm{Cl}^{-}$ secretion in a dose-dependent manner (Taylor and Baird, 1995). More importantly, berberine attenuated the large $\mathrm{Cl}^{-}$secretory current produced by agents that increase intracellular cAMP. However, the specific transport pathways responsible for the inhibitory effect of berberine on $\mathrm{Cl}^{-}$secretion have not been identified. Herein we report on a series of experiments designed to clarify which epithelial transport processes are affected by berberine. Using the short-circuit current technique, we studied the ability of berberine to inhibit $\mathrm{Cl}^{-}$secretion induced by cAMP in T84 cells. Using the pore-forming antibiotics nystatin and amphotericin $B$ to permeabilized the basolateral and apical membranes respectively, we were able to isolate membrane currents and assess the effects of berberine on (1) the apical membrane $\mathrm{Cl}^{-}$conductance, (2) the basolateral membrane $\mathrm{Na}^{+}-\mathrm{K}^{+}$-ATPase activity, and (3) the basolateral membrane $\mathrm{K}^{+}$conductance. Also, we explored the signaling involved in the antisecretory action of berberine in particular the role of protein kinases such as PKC, PKA, mitogen-activated protein kinase (MAPK), and membrane targets such as ion channels and transporters. Our results indicate that berberine inhibits $\mathrm{Cl}^{-}$ secretion by decreasing the basolateral membrane $\mathrm{K}^{+}$conductance and therefore $\mathrm{K}^{+}$recycling necessary for the generation of the favorable electrochemical gradient required for $\mathrm{Cl}^{-}$secretion.

\section{MATERIALS AND METHODS CELL CULTURE}

T84 cells (American Type Culture Collection, Manassas, VA, USA) were cultured in a 1:1 mixture of DMEM and Ham's F12 supplemented with $10 \%$ fetal bovine serum, $1 \%$ non-essential amino acids, $50 \mathrm{U} \cdot \mathrm{ml}^{-1}$ penicillin, $0.05 \mathrm{mg} \cdot \mathrm{ml}^{-1}$ streptomycin, and grown onto Costar Snapwell culture inserts (Corning, Dublin, Ireland) with an area of $1 \mathrm{~cm}^{2}$ for short-circuit current measurements or onto $24 \mathrm{~mm}$ Costar Transwell filters ( $0.4 \mu \mathrm{m}$ pore) for protein assays. Experiments were conducted on confluent monolayers 8-12 days after culture onto the permeable supports.

\section{TRANSEPITHELIAL TRANSPORT STUDIES}

T84 cells were grown onto Snapwell inserts and mounted in Ussing chambers (Physiologic Instruments, San Diego, CA, USA). Transepithelial potential difference was clamped to zero using an EVC-4000 voltage-clamp apparatus (World Precision Instruments, UK). The transepithelial short-circuit current $\left(I_{\mathrm{SC}}\right)$ was recorded using $\mathrm{Ag}-\mathrm{AgCl}$ electrodes in $3 \mathrm{M} \mathrm{KCl}$ agar bridges as previously described (Condliffe et al., 2001). Transepithelial resistance $\left(R_{\mathrm{t}}\right)$ was calculated by measuring the $I_{\mathrm{SC}}$ resulting from 5-s square voltage pulses $(2$ or $4 \mathrm{mV})$ imposed across the monolayer. All preparations were allowed to equilibrate for $30 \mathrm{~min}$ before the experiments were performed. Amiloride $(50 \mu \mathrm{M})$ was added at the start of the experiments to block $\mathrm{Na}^{+}$absorption. All experiments were performed at $37^{\circ} \mathrm{C}$. The $I_{\mathrm{SC}}$ was defined as positive for anion flow from the basolateral to apical chamber.

Specific apical $\mathrm{Cl}^{-}$channel conductance and basolateral $\mathrm{Na}^{+} / \mathrm{K}^{+}$pump and $\mathrm{K}^{+}$channel conductances were isolated and analyzed using a well-established technique consisting of selective membrane permeabilization using ionophores as previously described (DuVall et al., 1998). To investigate the activity of apical $\mathrm{Cl}^{-}$conductance in isolation, the basolateral membrane was permeabilized by addition of $200 \mu \mathrm{g} \cdot \mathrm{ml}^{-1}$ nystatin in the presence of an apical to basolateral $\mathrm{Cl}^{-}$gradient. Forskolin was then added to the apical and basolateral sides of the monolayers to activate the cystic fibrosis transmembrane conductance regulator (CFTR). Under these conditions, the $I_{\mathrm{SC}}$ represents the $\mathrm{Cl}^{-}$current $\left(I_{\mathrm{Cl}}\right)$ as $\mathrm{Cl}^{-}$moves down its concentration gradient through the CFTR channels in the apical plasma membrane.

To investigate the activity of basolateral $\mathrm{Na}^{+}-\mathrm{K}^{+}$-ATPase activity in isolation, the apical membrane was permeabilized by addition of $10 \mu \mathrm{M}$ amphotericin B. $\mathrm{Na}^{+}-\mathrm{K}^{+}$-ATPase activity was examined in monolayers bathed with medium in which $\mathrm{NaCl}$ was replaced by $\mathrm{N}$-methyl-D-glutamine chloride, such that the final bath $\mathrm{Na}^{+}$concentration was $25 \mathrm{mM}$ on both sides of the monolayers. Under short-circuit conditions, the resulting current is due to the transport of $\mathrm{Na}^{+}$across the basolateral membrane by the $\mathrm{Na}^{+}-\mathrm{K}^{+}$-ATPase $\left(I_{\mathrm{Na}}\right)$.

To investigate the activity of the basolateral $\mathrm{K}^{+}$conductance in isolation, the apical membrane was permeabilized by addition of $10 \mu \mathrm{M}$ amphotericin B in the presence of an apical to basolateral $\mathrm{K}^{+}$gradient. Ouabain $(100 \mu \mathrm{M})$ was added to the basolateral bath to inhibit $\mathrm{Na}^{+}-\mathrm{K}^{+}$-ATPase. The resulting $I_{\mathrm{SC}}$ is due to the movement of $\mathrm{K}^{+}$through channels in the basolateral membrane $\left(I_{\mathrm{K}}\right)$. The use of antibiotic-based ionophores to selectively permeabilized epithelial membranes is a well-established electrophysiological protocol since the 1980s to gain an insight into ion conductive properties at the opposite unpermeabilized membrane. Antibiotic ionophores used for transport studies are permselective for ions of similar size with the exception of valinomycin for $\mathrm{K}+$. The establishment of large transepithelial (transmembrane) ionic gradients for the ion under study and the use of selective channel blockers aid in extracting the conductive properties of the particular rheogenic ion transport pathway as was done in this study.

\section{PATCH-CLAMP RECORDINGS}

A small aliquot of Krebs solution containing single T84 cells was transferred into a 1-ml superfusion chamber mounted on the stage of an inverted microscope (Nikon Diaphot). Patch pipettes were prepared from capillary glass (GC150 F-10, Harvard Apparatus Ltd., Edenbridge, UK) using a programmable horizontal puller (DMZ-Universal Puller, Zeitz-Instruments GmbH, Munich, Germany) and had a resistance of 3-6 $\Omega$ when filled with the pipette solution. The reference electrode was an $\mathrm{Ag}-\mathrm{AgCl}$ wire in direct 
contact with the superfusion bath. Patch-clamp apparatus consisted of a CV-203BU headstage (Axon Instruments Inc., Union City, CA, USA) connected to an Axopatch 200B series amplifier. Experiments were performed using the whole-cell patch-clamp configuration and recorded membrane currents were filtered at $1 \mathrm{kHz}$ and digitized at $5 \mathrm{kHz}$. Membrane voltage was clamped from -100 to $+100 \mathrm{mV}$ with ramps of $20 \mathrm{mV}$ from an initial holding potential of $-50 \mathrm{mV}$. The protocols for patch-clamp and data analysis were established using pClamp 9.2 software (Axon Instruments Inc.) running on a PC, and data were stored for subsequent analysis. For patch-clamp measurements, the standard bath solution contained (in $\mathrm{mM}$ ): $\mathrm{NaCl} 140, \mathrm{KCl} 5.4, \mathrm{MgCl}_{2} 1, \mathrm{CaCl}_{2} 1.25$, glucose 12.2, and HEPES 10, buffered at $\mathrm{pH} 7.4$ with $\mathrm{NaOH}$. The patch pipette solution contained (in $\mathrm{mM}$ ): $\mathrm{K}$-gluconate $95, \mathrm{KCl} 30$, $\mathrm{Na}_{2} \mathrm{HPO}_{4} 4.8, \mathrm{KH}_{2} \mathrm{PO}_{4}$ 1.2, EGTA 1, Ca-gluconate 0.73, $\mathrm{MgCl}_{2}$ $1, \mathrm{Na}_{2}$ ATP 3, glucose 5 ( $\mathrm{pH} 7.2$ ). Drug actions were measured only after steady-state conditions were reached. All patch-clamp experiments were performed at $37^{\circ} \mathrm{C}$.

\section{IMMUNOPRECIPITATION AND WESTERN BLOTTING}

T84 cells were serum-starved for $24 \mathrm{~h}$ prior to treatment. Drugs were added to the basolateral side of the cell monolayers for the required time. After treatment cells were lysed and subjected to standard 10\% SDS-PAGE and Western blotting as previously described (Dilly et al., 2004). Immunoblots were developed using specific phospho-antibodies against human $\mathrm{PKC} \alpha, \mathrm{PKC} \delta, \mathrm{p} 42 / \mathrm{p} 44$ MAPK, and p38 MAPK. Immunoprecipitation assays for KCNQ1 were carried out as previously described (Dilly et al., 2004).

\section{PKA ASSAY}

PKA activity was detected using the PepTag ${ }^{\circledR}$ assay for nonradioactive detection of cAMP-dependent protein kinase. The kit was used according to manufacturer's instructions using $30 \mu \mathrm{g}$ of protein in each reaction http://www.promega.com/resources/ protocols/technical-bulletins/0/peptag-assay-for-nonradioactivedetection-of-pkc-or-campdependent-protein-kinase-protocol/. T84 cells were lysed by hypotonic shock on ice for $45 \mathrm{~min}$ (lysis buffer: $20 \mathrm{mM}$ tris, $\mathrm{pH} 7.4,0.5 \%$ non-ident P-40, $250 \mathrm{mM} \mathrm{NaCl}$, $3 \mathrm{mM}$ EDTA, $3 \mathrm{mM}$ EGTA, leupeptin $1 \mu \mathrm{g} / \mu \mathrm{l}, 500 \mathrm{mM}$ dithiothreitol, $5 \mathrm{mM}$ phenylmethylsulfonyl fluoride, complete mini EDTAfree protease inhibitor mixture tablets ( 1 tablet $/ 7 \mathrm{ml}$ of lysis buffer; Roche Applied Science) and phosphatase inhibitors.

\section{STATISTICAL ANALYSIS}

Densitometric analysis was performed using Genetools software (Syngene, Cambridge, UK). Statistical analysis of the data was obtained using paired $t$-test for analysis between two groups. ANOVA and Tukeys post hoc test for multiple analyses. $P$-values of 0.05 and less were considered to be significant. Data are expressed as mean \pm SEM unless specifically stated to be from a representative experiment.

\section{MATERIALS}

Phospho-PKCd/ $\theta$ (Ser $\left.{ }^{643 / 676}\right)$, p44/p42 MAPK, phospho-p42/p44 MAPK ( $\mathrm{Thr}^{202} / \mathrm{Tyr}^{204}$ ), and phospho-p38 MAPK ( ${ }^{2} r^{180} / \mathrm{Tyr}^{182}$ ) antibodies were from Cell Signaling Technologies (Hertfordshire,
UK). PKC $\alpha$ and PKAcI antibodies were from BD Transduction Antibodies (NJ, USA). Phospho-PKC $\alpha$ ( $\mathrm{Ser}^{657}$ ) antibody was from Upstate (Dublin, Ireland). KCNQ1 antibody was from Santa Cruz (CA, USA). Chromanol 293B was obtained from Tocris (Avonmouth, UK). Rottlerin, clotrimazole, SB202190, and HBDDE were purchased from Calbiochem (Nottingham, UK). (3R,4S)-(+)-N-[3-hydroxy-2,2-dimethyl-6(4,4,4-trifluorobutoxy)chroman-4-yl]-N-methylethanesulfonami de (HMR-1556) was kindly provided by Dr. Uwe Gerlach (Aventis Pharma Deutschland, Frankfurt-am-Main, Germany). All other chemicals were purchased from Sigma-Aldrich (Dublin, Ireland). All drugs were dissolved in DMSO or water as stock solutions and diluted appropriately. The final DMSO concentration was less than $0.1 \%$.

\section{RESULTS}

\section{BERBERINE INHIBITS CAMP-STIMULATED CI- SECRETION IN COLONIC EPITHELIAL CELLS}

Short-circuit current measurements across T84 monolayers under basal conditions revealed a small $I_{\mathrm{SC}}$ reflecting a low level of $\mathrm{Cl}^{-}$secretion. When the epithelium was treated with forskolin $(10 \mu \mathrm{M})$, the $I_{\mathrm{SC}}$ rapidly increased from $4 \pm 2$ to $48 \pm 6 \mu \mathrm{A} \cdot \mathrm{cm}^{-2}$ and remained significantly elevated for over $30 \mathrm{~min}$. Berberine when added to the basolateral solution at the peak of the forskolin response decreased the $I_{\mathrm{SC}}$ (control $46 \pm 5 \mu \mathrm{A} \cdot \mathrm{cm}^{-2}$, berberine $5 \pm 3 \mu \mathrm{A} \cdot \mathrm{cm}^{-2} ; n=8, P<0.01$; Figure 1A). The inhibitory

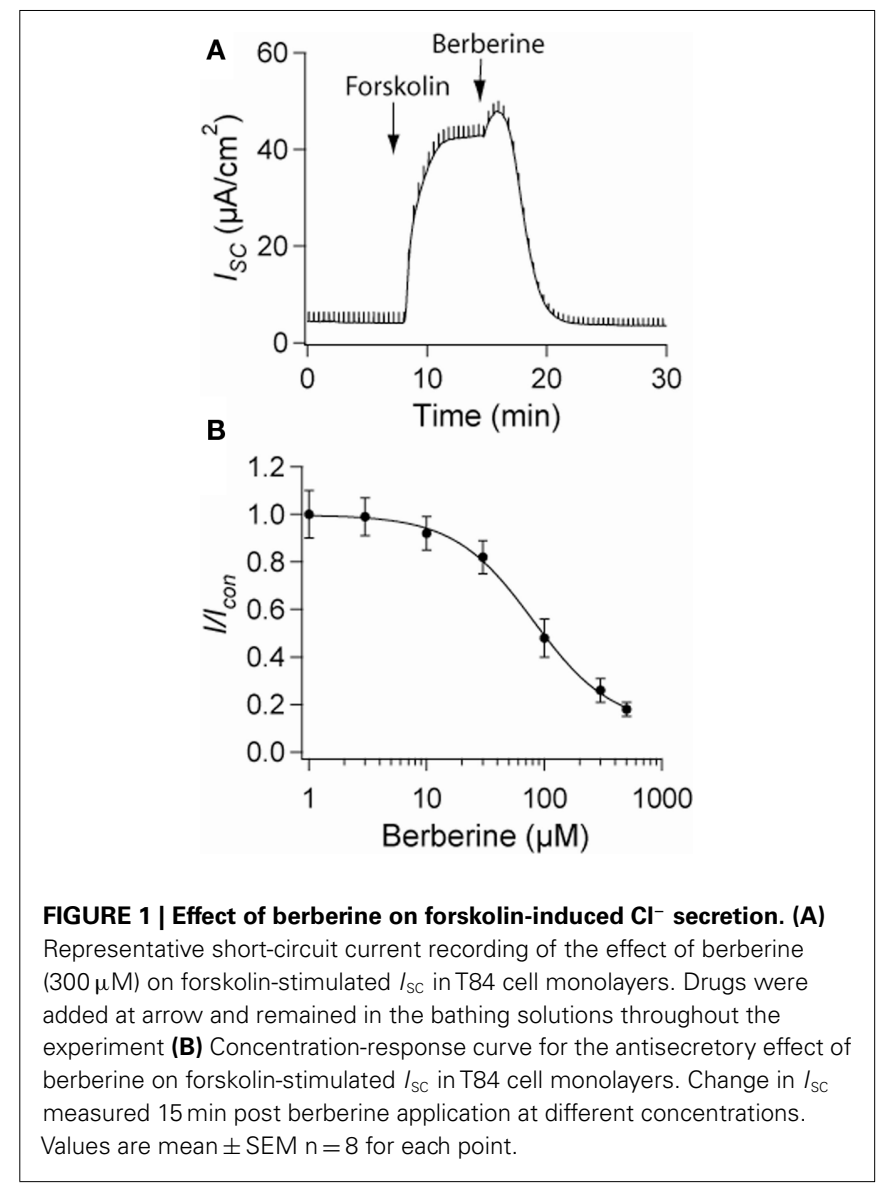


effect of berberine on forskolin-induced $\mathrm{Cl}^{-}$secretion was concentration-dependent between 10 and $300 \mu \mathrm{M}$ with an $\mathrm{IC}_{50}$ of $80 \pm 3 \mu \mathrm{M}$ (Figure 1B). No significant effect on $I_{S C}$ was observed when berberine was added in the absence of forskolin, however, subsequent treatment with forskolin failed to increase $I_{S C}$ (not shown). In approximately $75 \%$ of the experiments berberineinduced a small and transient increase in $I_{\mathrm{SC}}$ (Figure 1A). This response was prevented by addition of $\mathrm{BaCl}_{2}(2 \mathrm{mM})$ to the apical bath suggesting berberine also inhibits an apical $\mathrm{K}^{+}$conductance responsible for $\mathrm{K}^{+}$secretion (data not shown). Berberine treatment for as long as $2 \mathrm{~h}$ did not decrease the transepithelial resistance $R_{\mathrm{t}}$ compared to vehicle controls, suggesting that the effects of berberine, at the concentrations used in this study, were not due to cytotoxicity (Table $\mathbf{1}$ ).

\section{BERBERINE EFFECTS ON APICAL MEMBRANE CI- CONDUCTANCE AND BASOLATERAL $\mathrm{Na}^{+}-\mathrm{K}^{+}$-ATPase ACTIVITY AND $\mathrm{K}^{+}$CONDUCTANCE}

Nystatin, added to the basolateral bathing solution of T84 monolayers increased the apical membrane $\mathrm{Cl}^{-}$specific current $I_{\mathrm{Cl}}$ from $3 \pm 1$ to $14 \pm 2 \mu \mathrm{A} \cdot \mathrm{cm}^{-2}(n=6)$, this likely reflects a constitutively active apical membrane $\mathrm{Cl}^{-}$conductance. Subsequent addition of forskolin $(10 \mu \mathrm{M})$ further increased the $I_{\mathrm{Cl}}$ to $88 \pm 12 \mu \mathrm{A} \cdot \mathrm{cm}^{-2}$. Treatment of T84 cell monolayers with berberine $(300 \mu \mathrm{M})$ on either apical or basolateral bath for $15 \mathrm{~min}$ had no effect on either basal or forskolin-activated apical membrane $I_{\mathrm{Cl}}$ (Table 2).

The addition of amphotericin $\mathrm{B}$ to the apical bathing solution containing $25 \mathrm{mM} \mathrm{Na}^{+}$increased the basolateral membrane $\mathrm{Na}^{+}$specific pump current $I_{\mathrm{Na}}$ from $3 \pm 1$ to $16 \pm 3 \mu \mathrm{A} \cdot \mathrm{cm}^{-2}$ $(n=6)$. Under these conditions, the amphotericin-induced $I_{\mathrm{Na}}$ was completely inhibited by $100 \mu \mathrm{M}$ ouabain. When T84 monolayers were treated with berberine $(300 \mu \mathrm{M})$ for $10 \mathrm{~min}$, the

Table 1| Effect of berberine on transepithelial resistance.

\begin{tabular}{llll}
\hline Time (hours) & \multicolumn{3}{c}{$\boldsymbol{R}_{\mathbf{t}}, \mathbf{\Omega} \cdot \mathbf{c m}^{\mathbf{2}}$} \\
\cline { 2 - 4 } & Vehicle & Berberine $\mathbf{1 0 0} \boldsymbol{\mu} \mathbf{M}$ & Berberine $\mathbf{3 0 0} \boldsymbol{\mu} \mathbf{M}$ \\
\hline 0 & $1302 \pm 212$ & $1235 \pm 205$ & $1301 \pm 182$ \\
1 & $1287 \pm 234$ & $1198 \pm 192$ & $1246 \pm 235$ \\
2 & $1176 \pm 187$ & $1099 \pm 210$ & $1155 \pm 211$ \\
\hline
\end{tabular}

Transepithelial resistance $\left(R_{t}\right)$ was calculated using Ohms law by measuring the $I_{S C}$ resulting from $5 \mathrm{~s}$ square voltage pulses (2 or $4 \mathrm{mV}$ ) imposed across the monolayer. Values are mean $\pm S E M ; n=8$ for each group.

Table 2 | Berberine effect on membrane conductances.

\begin{tabular}{llll}
\hline Treatment & $\boldsymbol{I}_{\mathbf{C l}}\left(\boldsymbol{\mu} \mathbf{A} / \mathbf{c m}^{2}\right)$ & $\boldsymbol{I}_{\mathbf{N a}}\left(\boldsymbol{\mu} \mathbf{A} / \mathbf{c m}^{2}\right)$ & $\boldsymbol{I}_{\mathbf{K}}\left(\boldsymbol{\mu} \mathbf{A} / \mathbf{c m}^{2}\right)$ \\
\hline Basal & $14 \pm 2$ & $16 \pm 3$ & $53 \pm 4$ \\
Basal + berberine & $12 \pm 3$ & $13 \pm 3$ & $9 \pm 2^{* *}$ \\
Forskolin & $88 \pm 12$ & - & $94 \pm 2$ \\
Forskolin + berberine & $84 \pm 10$ & - & $15 \pm 4^{* *}$
\end{tabular}

Forskolin (10 (M) was added to stimulate CFTR and CAMP-dependent $K^{\prime}$ conductance. Berberine (300 (M) was added to the basolateral bath. The berberine effect was measured 15 min after the drug addition. $n=6$ for each group, ${ }^{*} P<0.05$. amphotericin-induced $I_{\mathrm{Na}}$ was not different from that of vehicle controls (Table 2).

When amphotericin $\mathrm{B}$ was added to the apical bath in the presence of an apical to basolateral $\mathrm{K}^{+}$gradient $(80: 5 \mathrm{mM})$ and basolateral ouabain $(100 \mu \mathrm{M})$, the $I_{\mathrm{K}}$ immediately began to increase and reached maximal levels within $15 \mathrm{~min}$ (from $5 \pm 3$ to $\left.53 \pm 4 \mu \mathrm{A} \cdot \mathrm{cm}^{-2} ; n=6\right)$. In these conditions, $I_{\mathrm{K}}$ was almost completely inhibited by addition of $\mathrm{BaCl}_{2}(2 \mathrm{mM})$, chromanol 293B $(10 \mu \mathrm{M})$, or HMR-1556 $(500 \mathrm{nM})$ to the basolateral bath (Figure 2A). When monolayers were treated with berberine $(300 \mu \mathrm{M}), I_{\mathrm{K}}$ was rapidly inhibited ( $53 \pm 4$ to $9 \pm 2 \mu \mathrm{A} \cdot \mathrm{cm}^{-2}$;
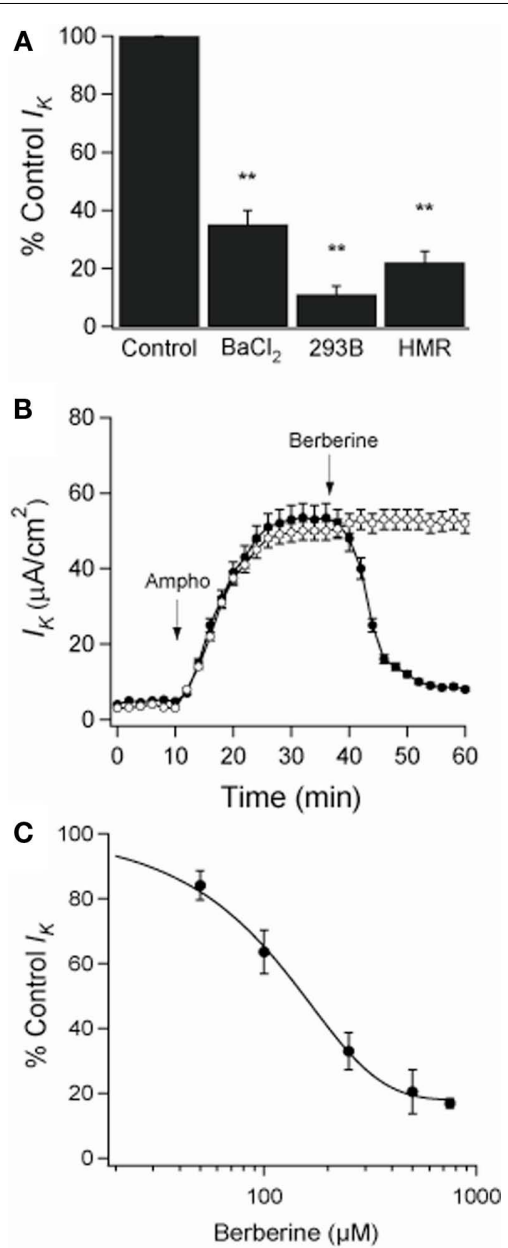

FIGURE 2 | Effect of berberine on basolateral $\mathrm{K}^{+}$current $\left(\mathrm{I}_{\mathrm{K}}\right)$ across apically permeabilized T84 cell monolayers. (A) Effect of KCNO1 channel inhibitors on $I_{K}$ in T84 cell monolayers. Amphotericin $B(10 \mu \mathrm{M})$ was added to apical bath after ouabain $(100 \mu \mathrm{M})$ was added to basolateral bath. $\mathrm{BaCl}_{2}$ (2 mM), chromanol 293B (10 $\mu \mathrm{M})$, or HMR-1556 (500 nM) were added to the basolateral bath. Values were measured at the point of maximal inhibition of $I_{\mathrm{K}}$ by each inhibitor. (B) Short-circuit currents recording of the effect of berberine $\left(300 \mu \mathrm{M}\right.$, filled circles) on $I_{K}$ across T84 cells monolayers compared to a vehicle control (DMSO $0.05 \%$, open circles). Drugs were added at arrow and remained in the bathing solutions throughout the experiment. Values are mean \pm SEM, ${ }^{*} P<0.01$ compared to controls, $n=6$ for each group. (C) The concentration dependence of the inhibitory effect of berberine on basolateral membrane $\mathrm{K}^{+}$current showed a half-maximal inhibition at $150 \mu \mathrm{M}$. 
$P<0.01, n=6$; Figure 2B) with half-maximal inhibition produced at a concentration of $150 \mu \mathrm{M}$ (Figure 2C).

\section{BERBERINE EFFECTS ON WHOLE-CELL POTASSIUM CURRENTS IN T84 CELLS}

Berberine produced a strong inhibitory effect on forskolinactivated basolateral membrane $I_{\mathrm{K}}$ in T84 monolayers (Table 2). The effect of berberine on cAMP-stimulated whole-cell currents in T84 cells was examined (Figure 3A). Forskolin $(10 \mu \mathrm{M})$ stimulated a mean maximal increase in whole-cell current of $359 \pm 71 \mathrm{pA}$ (at $\mathrm{Vp}=+100 \mathrm{mV} ; n=7, P<0.001)$. Berberine $(100 \mu \mathrm{M})$ addition to isolated T84 cells reduced the forskolin-activated current by $68 \%$ (corresponding to a reduction of $245 \pm 44 \mathrm{pA}$ (at

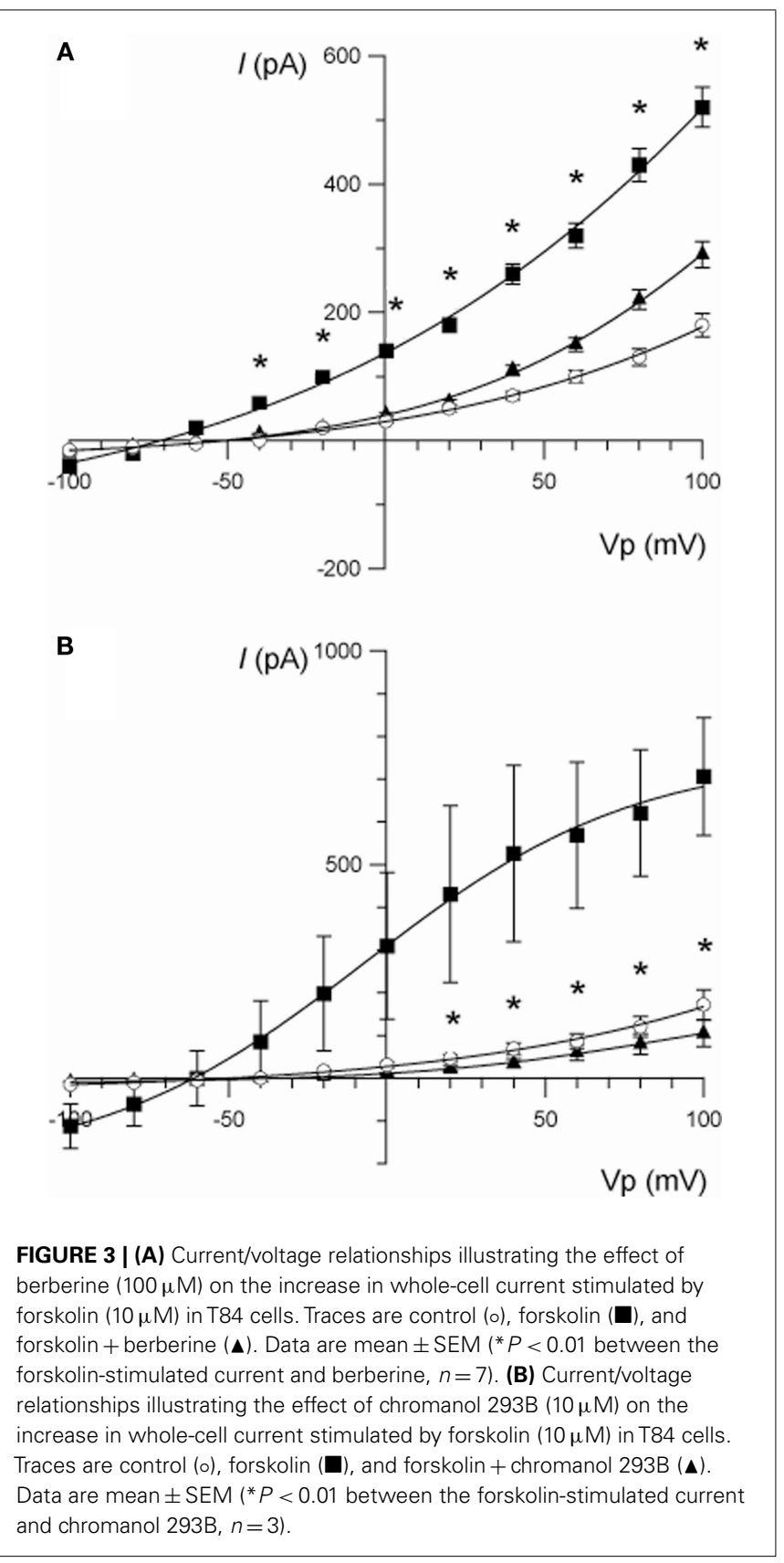

$\mathrm{Vp}=+100 \mathrm{mV}, n=7, P<0.01)$. Consistent with the increase in whole-cell current, forskolin-stimulated an increase in the chord conductance at $+100 \mathrm{mV}\left(\gamma_{+100}\right)$ from $1.7 \pm 0.3$ to $5.2 \pm 0.4 \mathrm{nS}$ $(P<0.001, n=7)$, which was reduced to $2.8 \pm 0.2 \mathrm{nS}(P<0.01$, $n=7)$ following treatment with berberine.

The identity of the $\mathrm{K}^{+}$channels underlying the current stimulated by forskolin and inhibited by berberine was investigated using a variety of $\mathrm{K}^{+}$channel blockers. Chromanol 293B (10 $\left.\mu \mathrm{M}\right)$ completely inhibited the forskolin-stimulated current below the level of the control current measured prior to the addition of forskolin (at $\mathrm{Vp}+100 \mathrm{mV}$ : forskolin $=665 \pm 193 \mathrm{pA}$; forskolin + chromanol $293 \mathrm{~B}=86 \pm 51 \mathrm{pA} ; P<0.05, n=3$; Figure 3B). Superfusion with chromanol 293B also reduced the forskolin-induced chord conductance at $+100 \mathrm{mV}$ from $7.2 \pm 1.4$ to $1.2 \pm 0.5 \mathrm{nS}(P<0.05$, $n=3$ ). Other specific $\mathrm{K}^{+}$channel inhibitors (of large and small conductance, $\mathrm{Ca}^{2+}$-dependent $\mathrm{K}^{+}$channels) such as iberiotoxin (BK, $200 \mathrm{nM}$ ), apamin (SK, $500 \mathrm{nM})$, and TRAM-34 (KCNN4, $500 \mathrm{nM})$ did not affect the forskolin-induced whole-cell $\mathrm{K}^{+}$ currents.

\section{BERBERINE EFFECT ON PROTEIN KINASES ACTIVITY IN T84 CELLS}

$\mathrm{PKC} \alpha$ activation was assessed by probing with a specific antibody to phospho-Ser ${ }^{657}$. Berberine treatment increased $\mathrm{PKC} \alpha$ phosphorylation levels at 5 and $10 \mathrm{~min}$ with fold increases of $6.4 \pm 0.8$ and $7.4 \pm 1.8$ respectively $(n=3, P<0.01)$ compared to vehicle controls (Figure 4A). PKC $\delta$ activity was measured using an antibody specific to phospho-Ser ${ }^{643}$. Berberine treatment had no effect on $\mathrm{PKC} \delta$ phosphorylation levels $(5 \mathrm{~min} 1.1 \pm 0.1 ; 10 \mathrm{~min} 0.9 \pm 0.1$; $n=3$ ) compared to vehicle controls within the time period assayed (Figure 4B). These results show that berberine selectively activates the classical PKC $\alpha$ with no effect on the novel PKC $\delta$. Berberine pretreatment activated PKA at $10 \mathrm{~min}$ with a fold increase of $2.2 \pm 0.1$ compared to vehicle controls ( $n=3, P<0.001$; Figure 4C). Pretreatment for $10 \mathrm{~min}$ with $100 \mu \mathrm{M}$ HBDDE, a selective PKC $\alpha$ inhibitor at this concentration (Kashiwada et al., 1994), prevented berberine-induced PKA activation ( $1.0 \pm 0.1 ; n=3$; Figure 4C). This result indicates that PKA is activated in response to berberine and is downstream to PKC $\alpha$ activation.

Activation of $\mathrm{p} 38$ MAPK was assessed by probing with a specific antibody to phospho-Thr ${ }^{180} / \mathrm{Tyr}^{182}$. Berberine treatment induced p38 MAPK phosphorylation at $5 \mathrm{~min}$ with a fold increase of $1.8 \pm 0.02(n=3, P<0.05$; Figure 5A). The activity of $\mathrm{p} 42 / \mathrm{p} 44$ MAPK was measured using an antibody specific to phospho$\mathrm{Thr}^{202} / \mathrm{Tyr}^{204}$. Treatment with berberine had no effect on basal p42/p44 MAPK phosphorylation levels compared to vehicle controls $(0.8 \pm 0.3, P<0.04, n=4)$ within the time points assayed (Figure 5B). However, pre-treatment of the cells with berberine for $5 \mathrm{~min}$ inhibited activation of p42/p44 MAPK by epidermal growth factor (EGF $100 \mathrm{ng} \cdot \mathrm{ml}^{-1}$ ) with similar potency to that of PD98059 $(20 \mu \mathrm{M})$, a specific MEK1 inhibitor that prevent receptor-mediated activation of p42/p44 MAPK, (EGF $10.3 \pm 1.1$; berberine + EGF $1.6 \pm 0.7$; PD98059 + EGF $0.6 \pm 0.1$; $n=4, P<0.01$; Figure 5B). These results confirm that berberine selectively activates the p38 MAPK isoform but does not activate $\mathrm{p} 42 / \mathrm{p} 44$ MAPK isoforms. Moreover, berberine prevents the EGF-induced activation of p42/p44 MAPK. 


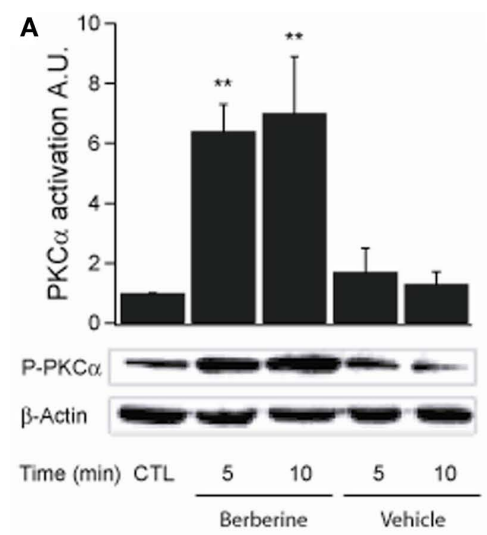

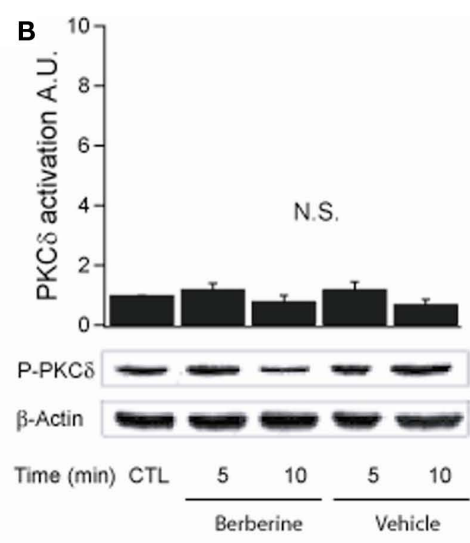

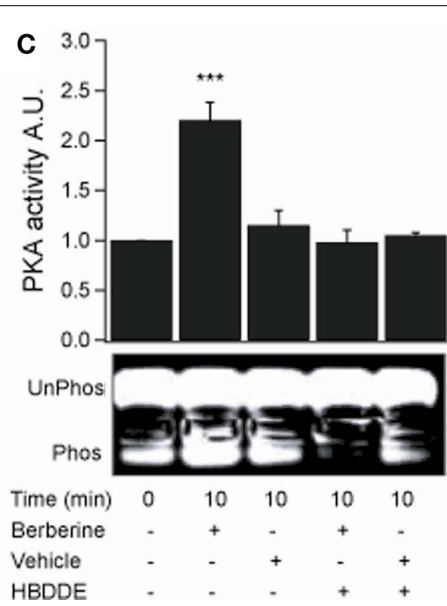

FIGURE 4 | Berberine effect on PKC isoforms and PKA activity in T84 cells. (A) Representative blot of PKC $\alpha$ phosphorylation levels at $\mathrm{Ser}^{657}$ in cellular extracts from T84 cells after berberine treatment $(300 \mu \mathrm{M})$ for 5 and 10 min compared to vehicle controls. (B) Representative blot of PKC $\delta$ phosphorylation levels at $\mathrm{Ser}^{643}$ in cellular extracts from T84 after berberine treatment $(300 \mu \mathrm{M})$ cells for 5 and 10 min compared to vehicle controls. Beta-actin was used as an internal control for protein loading. The graphs represent densitometric analysis of PKC blots or PKA activity assays. Values are given as fold changes in PKC phosphorylation (activation) or PKA activity respect to an untreated control. Values are displayed as mean \pm SEM $(n=3$ for each group, ${ }^{* *} P<0.01$ ). (C) Representative blot of PKA phosphorylation levels in cellular extracts from T84 after berberine treatment $(300 \mu \mathrm{M})$ cells for $10 \mathrm{~min}$ compared to vehicle controls and cells pretreated for $10 \mathrm{~min}$ with $100 \mu \mathrm{M}$ HBDDE, a selective PKC $\alpha$ inhibitor.

\section{BERBERINE INHIBITION OF CAMP-STIMULATED CI- SECRETION IS MEDIATED BY PROTEIN KINASES}

To assess the role of berberine-induced protein kinase activation on its antisecretory effect, T84 monolayers mounted in Ussing chambers were pre-treated with specific kinase inhibitors. Treatment of T84 monolayers with the PKC $\alpha$ inhibitor HBDDE and the specific p38 MAPK inhibitor SB202190 (10 $\mu \mathrm{M})$ had no effect on basal or forskolin-stimulated $I_{\mathrm{SC}}$. However, HBDDE significantly reduced the inhibitory effect of berberine on $I_{S C}$ by $65 \pm 7 \%$ (Figure 6A). SB202190 also reduced the effect of berberine but only by $14 \pm 5 \%$ (Figure 6A). Co-incubation with both inhibitors inhibited the effect of berberine by $82 \pm 4 \%$ suggesting parallel and synergistic signaling pathways. In contrast, inhibitors of PKC $\delta$ (rottlerin $10 \mu \mathrm{M}$ ) and p42/p44 MAPK (PD98059 $20 \mu \mathrm{M}$ ) failed to prevent the antisecretory effect of berberine. Figure $6 \mathrm{~B}$ shows percentage of inhibition of the berberine antisecretory action on forskolin-stimulated $I_{\mathrm{SC}}$ by several kinase inhibitor treatments.

Berberine pre-treatment increased the association of $\mathrm{PKC} \alpha$ with the KCNQ1 channel at $5 \mathrm{~min}$ with a fold increase of $2.4 \pm 0.1$ ( $n=3, P<0.05$; Figure 7A). Upon activation, PKA catalytic subunits (PKAcI) dissociate from their regulatory subunits and interact with their substrates. Berberine treatment increased PKAcI association with the KCNQ1 channel with a fold increase of $2.2 \pm 0.4(n=3, P<0.05$; Figure 7B). These experiments demonstrate the association of two kinases, PKC $\alpha$ and PKAcI, with the KCNQ1 channel upon treatment with berberine.

\section{DISCUSSION}

The results from this study show that the plant alkaloid berberine inhibits cAMP-dependent $\mathrm{Cl}^{-}$secretion through a kinasedependent inhibition of the KCNQ1 potassium channel located at the basolateral membrane of human colonic T84 cells. These data identify the ion channel target of berberine to produce inhibition of transepithelial $\mathrm{Cl}^{-}$secretion which we described in early studies in human colonic epithelia (Taylor et al., 1999). Taken together our results are consistent with the hypothesis that blockade of $\mathrm{Cl}^{-}$ secretion by berberine in colonic epithelia is secondary to blockade of basolateral membrane $\mathrm{K}^{+}$channels involved in cAMP-regulated $\mathrm{Cl}^{-}$secretory pathways.

At least two types of $\mathrm{K}^{+}$channels are present in T84 cells (Barrett and Keely, 2000; Kunzelmann and Mall, 2002). One channel is activated by agents that elevate cytosolic $\mathrm{Ca}^{2+}$ and has been identified as the KCNN4 channel (Warth et al., 1999). A separate $\mathrm{K}^{+}$channel is activated by cAMP-dependent agonists. Electrophysiological and pharmacological studies have demonstrated this $\mathrm{K}^{+}$conductance to correspond to the KCNQ1 channel (Schroeder et al., 2000) and this channel has been shown to be rate-limiting for secretion in colon (Preston et al., 2010). In our study, berberine significantly reduced the basolateral membrane $\mathrm{K}^{+}$conductance. This conductance was stimulated by the cAMP-dependent agonist forskolin and was sensitive to basolateral addition of $\mathrm{Ba}^{2+}$, a nonspecific $\mathrm{K}^{+}$channel blocker, and chromanol 293B, and HMR-1556, two specific KCNQ1 channel blockers, suggesting the main component of the basolateral $\mathrm{K}^{+}$conductance is composed of current flow through KCNQ1 channels. Similarly, berberine inhibited a cAMP-stimulated and chromanol 293B-sensitive whole-cell conductance, suggesting berberine inhibits KCNQ1 channels. Berberine had no effect on the apical $\mathrm{Cl}^{-}$conductance nor did it affect the basolateral $\mathrm{Na}^{+}-\mathrm{K}^{+}$-ATPase pump activity determined as ouabain-sensitive basolateral membrane $\mathrm{Na}^{+}$current. Therefore, this data suggests berberine exerts its antisecretory effect primarily by inhibiting KCNQ1 channels, thus, decreasing $\mathrm{K}^{+}$recycling at the basolateral membrane.

Recent studies have examined the effects of berberine on protein kinase activity in several tissues. These reports have shown that the antihyperglycemic activity of berberine is mediated by 
A

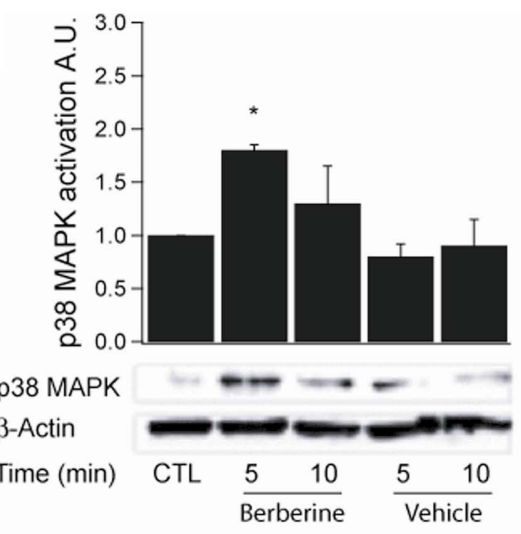

B

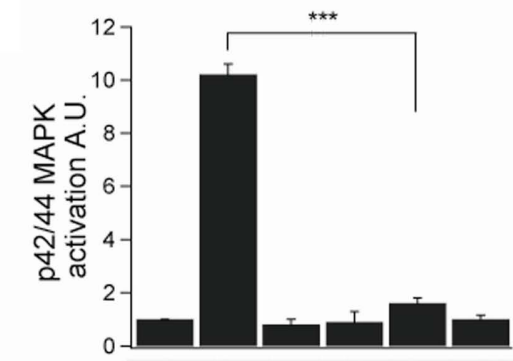

P-p42/44 MAPK p42/44 MAPK

Time (min) Berberine

Vehicle EGF

PD98059

FIGURE 5 | Berberine effect on MAPK signaling in T84 cells. (A) Representative blot of p38 MAPK phosphorylation levels at Thr ${ }^{180} / \mathrm{Tyr}^{182}$ in cellular extracts from T84 cells after berberine treatment $(300 \mu \mathrm{M})$ for 5 and 10 min compared to vehicle controls. (B) Representative blot of p42/p44 MAPK phosphorylation levels at $\mathrm{Thr}^{202} / \mathrm{Ty}^{204}$ in cellular extracts from T84 cells after berberine treatment $(300 \mu \mathrm{M})$ for 5 and $10 \mathrm{~min}$ compared to vehicle controls. T84 cells were treated with EGF $\left(100 \mathrm{ng} \cdot \mathrm{ml}^{-1}\right)$ for $5 \mathrm{~min}$ to stimulate p42/p44 MAPK phosphorylation. PD98059 $(20 \mu \mathrm{M})$ was added 15 min prior EGF-treatment. B-actin was used as an internal control for protein loading. The graphs represent densitometric analysis of blots. Values are given as fold changes in MAPK phosphorylation (activation) respect to an untreated control. Values are displayed as mean $\pm \operatorname{SEM~}(n=3$ for each group, ${ }^{*} P<0.05,{ }^{* *} P<0.001$ ).

activation of $\mathrm{p} 38 \mathrm{MAPK}$ and AMP-activated protein kinase (Cheng et al., 2006; Lee et al., 2006). The antiproliferative activity of berberine has been reported to be mediated by inhibition of cyclin-dependent kinases and the MAPK pathway in several tissues (Liang et al., 2006; Mantena et al., 2006). In T84 cells, no effect on basal p42/44 MAPK activity was observed, however, berberine did prevent EGF-induced activation of p42/44 MAPK. Several studies have described the ability of EGF receptor-mediated signaling in regulating $\mathrm{Cl}^{-}$secretion though MAPK (Bertelsen et al., 2004). Therefore, it is possible that berberine may also reduce $\mathrm{Cl}^{-}$secretion by interfering with the EGF signaling. Also, the inhibitory effect of berberine on EGF signaling may be relevant in the antiproliferative action of berberine.
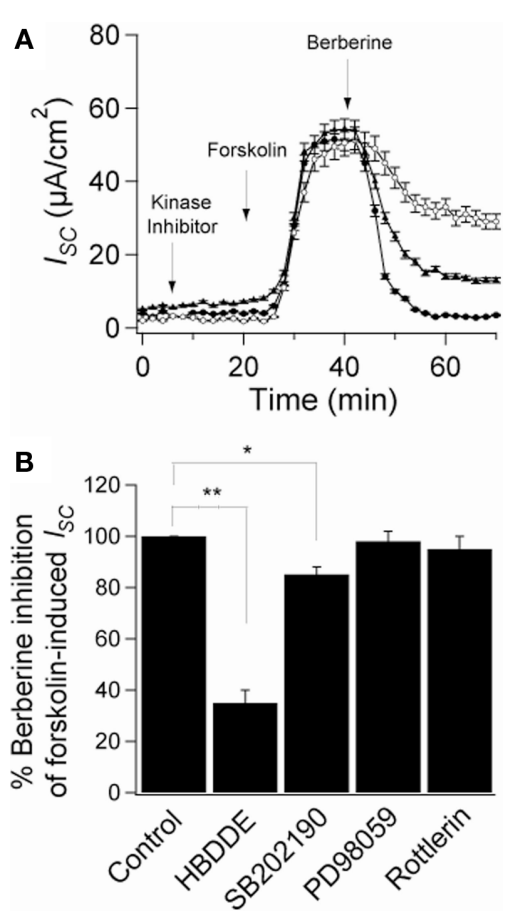

FIGURE 6 | Role of protein kinases on the antisecretory effect of berberine. (A) Short-circuit current recordings in T84 cell monolayers of the effect of protein kinases inhibitors on the antisecretory effect of berberine $(300 \mu \mathrm{M})$. Cells were pre-incubated for $15 \mathrm{~min}$ with $\operatorname{HBDDE} 100 \mu \mathrm{M}(\mathbf{\Delta})$, SB202190 $10 \mu \mathrm{M}$ (o), or vehicle DMSO 0.05\% (•). (B) Mean \pm SEM ( $n=6)$ change in total $I_{\mathrm{SC}}$ caused by preincubation with several kinase inhibitors on the antisecretory effect of berberine on forskolin-stimulated $I_{\mathrm{Sc}}$. Values are mean \pm SEM, $n=6,{ }^{*} P<0.05,{ }^{*} P<0.01$ compared to controls.

Berberine activated p38 MAPK, PKA, and PKC $\alpha$. Activation of PKA was observed to be dependent on PKC $\alpha$ activity, and this is the first study to demonstrate berberine-induced activation of PKA and PKC $\alpha$. Upon activation by berberine, both kinases were shown to transiently associate with the KCNQ1 channel even though both kinases remained activated for a longer period. Several studies have demonstrated regulation of $\mathrm{K}^{+}$channels by protein kinases. We have previously shown that estrogen causes a female-gender specific inhibition of KCNQ1 channels in rat colonic crypts, producing an antisecretory response which is also dependent on PKA activation and association with the KCNQ1 channel (O'Mahony et al., 2009). Therefore, we investigated the role of berberineinduced kinase activity on the antisecretory effect of berberine. Using specific kinase inhibitors we demonstrated that the antisecretory effect of berberine could be halved by the PKC $\alpha$ inhibitor HBDDE. Pre-treatment with SB202190, a specific inhibitor of p38 MAPK, also significantly decreased the effect of berberine on secretion, although to a much lesser degree. In agreement with these findings, several studies have shown that the phorbol ester PMA inhibits the basolateral $\mathrm{K}^{+}$conductance of T84 cells and that this effect reduces transepithelial $\mathrm{Cl}^{-}$secretion (Matthews et al., 1993; Reenstra, 1993). The molecular mechanism by which berberineinduced activation of PKC $\alpha$ and p38 MAPK inhibits basolateral KCNQ1 channels in T84 is an important goal of future studies. 


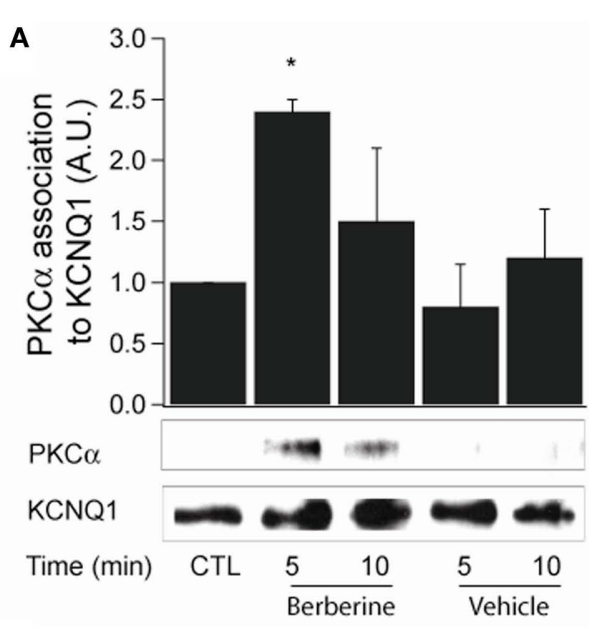

B

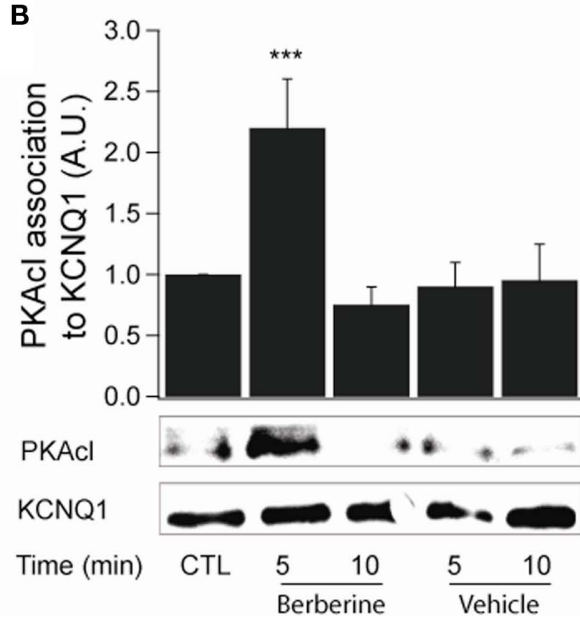

FIGURE 7 | Berberine effect on protein kinase association with KCNQ1 channel. (A) Representative blot of PKC $\alpha$ association with the KCNQ1 channel in response to berberine $(300 \mu \mathrm{M})$ in T84 cells. (B). Representative blot of $\mathrm{PKACl}$ association with the $\mathrm{KCNQ} 1$ ion channel in response to berberine $(300 \mu \mathrm{M})$ in T84 cells. Total KCNQ1 pools were

immunoprecipitated from total cellular lysates using an antibody specific to KCNQ1. Associated PKC $\alpha$ and PKAcl were quantified by Western blot analysis. The graphs represent densitometric analysis at specific time points of berberine treatment compared to vehicle controls. Values are given as fold changes in kinase association with KCNQ1 respect to an untreated control. Values are displayed as mean \pm SEM $(n=3$ for each group, $\left.{ }^{*} P<0.05,{ }^{*}{ }^{*} P<0.001\right)$.

One possibility to be considered is a change in the phosphorylation state of the channel protein, which is an important determinant of $\mathrm{K}^{+}$channel activity (Kathöfer et al., 2003; Kurokawa et al., 2003; Li et al., 2004) and which we have shown to mediate the estrogeninduced inhibition of KCNQ1 in rat colonic crypts (O'Mahony et al., 2007).

The present study has shown activation of PKA by berberine. It is well documented that activation of these enzyme lead to an increase in CFTR activity in colonic crypts (Schultheiss and Diener, 1998; Barrett and Keely, 2000; Kunzelmann and Mall, 2002). However, in this study berberine did not affect the apical $\mathrm{Cl}^{-}$current but had an overall inhibitory effect on $\mathrm{Cl}^{-}$secretion.
This paradox of activation of PKA without activation of CFTR can be explained if we consider that the cAMP-PKA pathway is tightly regulated at several levels to maintain specificity in the multitude of signal inputs (Tasken and Aandahl, 2004; Cooper, 2005). Ligand-induced changes in cAMP concentration vary in duration, amplitude, and localization into the cell, and cAMP microdomains are shaped by adenylyl cyclases that form cAMP as well as phosphodiesterases that degrade cAMP. Different PKA isozymes with distinct biochemical properties and cell-specific expression contribute to cell and organ specificity. Activated kinase anchoring proteins target PKA to specific substrates and distinct subcellular compartments providing spatial and temporal specificity for mediation of biological effects channeled through the cAMP-PKA pathway (McConnachie et al., 2006). Therefore, the activation of PKA by berberine does not necessarily imply phosphorylation and activation of CFTR located in the apical membrane.

Berberine is freely permeable across human intestinal epithelia and its absorption is significantly increased by P-glycoprotein inhibitors (Pan et al., 2002). It is possible that berberine interacts with a known receptor to effect its antisecretory action. Recently berberine has been shown to affect the activity of sex steroid receptors including the androgen receptor (antagonist) in prostate cancer cells ( $\mathrm{Li}$ et al., 2011) and the pregnane $\mathrm{X}$ receptor (agonist) in HepG2 cells (Yu et al., 2011). Berberine has been shown to enhance the anticancer effect of estrogen receptor antagonists on human breast cancer cells (Liu et al., 2009). The only known receptor-mediated inhibition of KCNQ1 channels in intestine is the estrogen receptor (O'Mahony et al., 2007). 17-B estradiol (E2) inhibits $\mathrm{Cl}^{-}$secretion via $\mathrm{PKC}$ and PKA dependent phosphorylation of the KCNQ1:KCNE3 $\mathrm{K}^{+}$channels in colonic crypts and berberine displays a remarkably similar mechanism of antisecretory action to E2 (both inhibit KCNQ1 channels by protein kinase phosphorylation and neither molecule inhibits CFTR). It is possible that berberine modulates estrogen receptor signaling in intestinal cells to inhibit KCNQ1 channels similar to E2. The chemical structure of berberine is similar to the novel GPR30 receptor agonist G-1 and this orphan estrogen receptor may also be a target of berberine. A hypothetical schema of the antisecretory action of berberine in intestinal epithelium is presented in Figure 8.

The ability of berberine to inhibit salt and water secretion from native intestinal tissue, as evidenced by blockade of stimulated $I_{\mathrm{SC}}$ in rabbit and rat colon in vitro, raises the distinct possibility that berberine and related compounds may display utility in the clinical treatment of secretory diarrhoeas. High doses of berberine have already been administered orally to humans (Rabbani et al., 1987; Tang and Eisenbrand, 1992), and can be therapeutically safe over the long term. In support of this view, we found that berberine had no detectable effect on the transepithelial resistance of T84 monolayers over a $2-\mathrm{h}$ treatment period. Thus, berberine may inhibit basal and cAMP-induced fluid secretion from intestine without affecting the net transport and absorption of nutrient substrates or absorptive capacity. In fact, berberine has been shown to stimulate $\mathrm{Na}^{+}$absorption (Tai et al., 1981). Unlike most antidiarrheals, berberine exhibits several pharmacological actions useful to the treatment of secretory diarrhea. Firstly, it reduces the cause of infection via its antimicrobial activity. Secondly, berberine increases stool transit time through the 


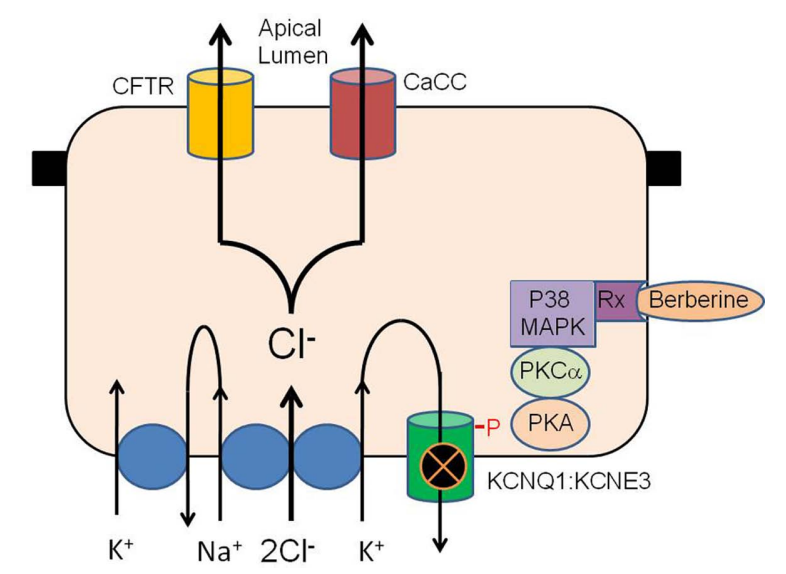

FIGURE 8 | Hypothetical schema of the antisecretory action of berberine in intestinal epithelium. Berberine activates p38 MAPK, PKC and PKA to phosphorylate the KCNQ1:KCNE3 $\mathrm{K}^{+}$channel causing the channel to become inactive either through closure or removal from the plasma membrane. Inhibition of basolateral $\mathrm{K}^{+}$channel reduces the electrical driving force for $\mathrm{Cl}^{-}$exit across the apical membrane through CFTR and calcium-activated $\mathrm{Cl}^{-}$channels. The receptor transducing the response to berberine may be the estrogen receptor or GPR30/GPCR as previously described for similar antisecretory and rapid protein kinase responses to estrogen in the intestine.

intestine via its antimotility action. Finally, as shown here, berberine decreases basolateral membrane $\mathrm{K}^{+}$recycling, thus reducing the electrical driving force for whole secretory process in the enterocytes.

Other laboratories have also explored the use of $\mathrm{K}^{+}$channel blockers to inhibit epithelial $\mathrm{Cl}^{-}$secretion. The antifungal antibiotic, clotrimazole, has been shown to prevent fluid and electrolyte secretion in rabbit and mouse intestine triggered by $\mathrm{Ca}^{2+}$ and cAMP-mediated agonists via specific inhibition of basolateral K ${ }^{+}$conductances (Rufo et al., 1997). Furthermore, levamisole (and other phenylimidazothiazoles) inhibits $\mathrm{Ca}^{2+}$ - and cAMPactivated $\mathrm{Cl}^{-}$secretion in T84 cell monolayers and isolated human

\section{REFERENCES}

Bachmann, A., Quast, U., and Russ, U. (2001). Chromanol 293B, a blocker of the slow delayed rectifier $\mathrm{K}+$ current (IKs), inhibits the CFTR $\mathrm{Cl}$ - current. Naunyn Schmiedebergs Arch. Pharmacol. 363, 590-596.

Barrett, K. E., and Keely, S. J. (2000). Chloride secretion by the intestinal epithelium: molecular basis and regulatory aspects. Annu. Rev. Physiol. 62, 535-572.

Bertelsen, L. S., Barrett, K. E., and Keely, S. J. (2004). Gs protein-coupled receptor agonists induce transactivation of the epidermal growth factor receptor in T84 cells: implications for epithelial secretory responses. $J$. Biol. Chem. 279, 6271-6279.

Cheng, Z., Pang, T., Gu, M., Gao, A. H., Xie, C. M., Li, J. Y., Nan,
F. J., and Li, J. (2006). Berberinestimulated glucose uptake in L6 myotubes involves both AMPK and p38 MAPK. Biochim. Biophys. Acta 1760, 1682-1689.

Condliffe, S. B., Doolan, C. M., and Harvey, B. J. (2001). 17 $\beta$-Oestradiol acutely regulates $\mathrm{Cl}$ - secretion in rat distal colonic epithelium. J. Physiol. 530, 47-54.

Cooper, D. M. (2005). Compartmentalization of adenylate cyclase and cAMP signalling. Biochem. Soc. Trans. 33, 1319-1322.

Dharmsathaphorn, K., McRoberts, J. A., Mandel, K. G., Tisdale, L. D., and Masui, H. (1984). A human colonic tumor cell line that maintains vectorial electrolyte transport. Am. J. Physiol. 246(Pt 1), G204-G208.

distal colon, apparently by blocking basolateral $\mathrm{K}^{+}$channels (Mun et al., 1998). Greger and colleagues noted that a group of chromanol compounds selected from agents screened for the ability to block $I_{\mathrm{SC}}$ in isolated rabbit colon turned out to be ineffective as $\mathrm{Cl}^{-}$channel blockers, but effective as blockers of $\mathrm{K}^{+}$channel activity elicited by cAMP-dependent agonists. The most potent of these was chromanol 293B (Lohrmann et al., 1995), which here was shown to block KCNQ1 channels in T84 cells. Chromanol 293B has been described to block CFTR currents when expressed in Xenopus oocytes (Bachmann et al., 2001) but this has not been observed in native epithelia. In our study, the KCNQ1 inhibitors, chromanol 293B, and HMR-1556 were added from the basolateral side without affecting apical $\mathrm{Cl}^{-}$currents. The inhibitory effects of these molecules on transepithelial $\mathrm{Cl}^{-}$secretion is indirect via block of KCNQ1 channels. Like chromanol 293B, berberine also reduced the basolateral $\mathrm{K}^{+}$current activated by cAMP-dependent agonists. Our finding that berberine has a marked inhibitory effect on basolateral KCNQ1 channel current in T84 cells highlights this component of the intestinal $\mathrm{Cl}^{-}$secretory process as a target for new antidiarrhoeal strategies. Identification of the mechanism of kinase regulation of basolateral $\mathrm{K}^{+}$channels in colonic epithelia and a better understanding of the signaling processes involved may provide a basis for the development of new antisecretory drugs with greater potency and specificity.

In summary, based on the results of our previous studies in rat colon in vitro and the present studies in T84 cells monolayers, we propose that the effect of berberine on chloride ion secretion in intestine is mediated by a protein kinase-dependent reduction in basolateral KCNQ1 channel activity.

\section{ACKNOWLEDGMENTS}

This work was supported by The Wellcome Trust Biomedical Research Collaboration Grant GR059395FR with Dr. Ko (CUHK), a Higher Education Authority of Ireland PRTLI Grants cycle 1 and 3, and Health Research Board of Ireland. R. Alzamora was recipient of a Wellcome Trust Studentship Prize 06379/Z/01/Z. We thank Wallace C. Y. Yip (Chinese University of Hong Kong) for his technical support.

Dilly, K. W., Kurokawa, J., Terrenoire, C., Reiken, S., Lederer, W. J., Marks, A. R., and Kass, R. S. (2004). Overexpression of grbeta2-adrenergic receptors cAMP-dependent protein kinase phosphorylates and modulates slow delayed rectifier potassium channels expressed in murine heart: evidence for receptor/channel co-localization. J. Biol. Chem. 279, 40778-40787.

DuVall, M. D., Guo, Y., and Matalon, S. (1998). Hydrogen peroxide inhibits cAMP-induced Cl- secretion across colonic epithelial cells. Am. J. Physiol. Cell Physiol. 275, C1313-C1322.

Farthing, M. J. (2006). Antisecretory drugs for diarrheal disease. Dig. Dis. 24, 47-58.

Field, M. (2003). Intestinal ion transport and the pathophysiology of diarrhea. J. Clin. Invest. 111, 931-943.

Guandalini, S., Fasano, A., Migliavacca, M., Marchesano, G., Ferola, A., and Rubino, A. (1987). Effects of berberine on basal and secretagogue-modified ion transport in the rabbit ileum in vitro. J. Pediatr. Gastroenterol. Nutr. 6, 953-960.

Heitzmann, D., and Warth, R. (2008). Physiology and pathophysiology of potassium channels in gastrointestinal epithelia. Physiol. Rev. 88, 1119-1182.

Ivanovska, N., and Philipov, S. (1996). Study on the anti-inflammatory actions of Berberis vulgaris root extract, alkaloid fractions and pure alkaloid. Int. J. Immunopharmacol. 18, 553-561. 
Iwasa, K., Lee, D. U., Kang, S. I., and Wiegrebe, W. (1998). Antimicrobial activity of 8-alkyl- and 8-phenylsubstituted berberines and their 12bromo-derivatives. J. Nat. Prod. 61, 1150-1153.

Kashiwada, Y., Huang, L., Ballas, L. M., Jiang, J. B., Janzen, W. P., and Lee, K. H. (1994). New hexahydroxybiphenyl derivatives as inhibitors of protein kinase C. J. Med. Chem. 37, 195-200.

Kathöfer, S., Rockl, K., Zhang, W., Thomas, D., Katus, H., Kiehn, J., Kreye, V., Schoels, W., and Karle, C. (2003). Human grbeta3-adrenoreceptors couple to KVLQT1/MinK potassium channel in Xenopus oocytes via protein kinase $\mathrm{C}$ phosphorylation of the KVLQT1 protein. Naunyn Schmiedebergs Arch. Pharmacol. 368, 119-126.

Kunzelmann, K., and Mall, M. (2002). Electrolyte transport in the mammalian colon: mechanisms and implications for disease. Physiol. Rev. 82, 245-289.

Kurokawa, J., Chen, L., and Kass, R. S. (2003). Requirement of subunit expression for cAMP-mediated regulation of a heart potassium channel. Proc. Natl. Acad. Sci. U.S.A. 100, 2122-2127.

Lau, C. W., Yao, X. O., Ko, W. H., and Huang, Y. (2001). Cardiovascular actions of berberine. Cardiovasc. Drug Rev. 19, 234-244.

Lee, Y. S., Kim, W. S., Kim, K. H., Yoon, M. J., Cho, H. J., Shen, Y., Ye, J. M., Lee, C. H., Oh, W. K., Kim, C. T., Hohnen-Behrens, C., Gosby, A., Kraegen, E. W., James, D. E., and Kim, J. B. (2006). Berberine, a natural plant product, activates AMPactivated protein kinase with beneficial metabolic effects in diabetic and insulin-resistant states. Diabetes 55, 2256-2264.

Li, J., Cao, B., Liu, X., Fu, X., Xiong, Z., Chen, L., Sartor, O., Dong, Y., and Zhang, H. (2011). Berberine suppresses androgen receptor signaling in prostate cancer. Mol. Cancer Ther. PMID: 21613449. [Epub ahead of print].

Li, Y., Langlais, P., Gamper, N., Liu, F, and Shapiro, M. S. (2004). Dual phosphorylations underlie modulation of unitary KCNQ K+ channels by Src tyrosine kinase. J. Biol. Chem. 279, 45399-45407.

Liang, K. W., Ting, C. T., Yin, S. C., Chen, Y. T., Lin, S. J., Liao, J. K., and Hsu, S. L. (2006). Berberine suppresses MEK/ERK-dependent Egr-1 signaling pathway and inhibits vascular smooth muscle cell regrowth after in vitro mechanical injury. Biochem. Pharmacol. 71, 806-817.

Liu, J., He, C., Zhou, K., Wang, J., and Kang, J. X. (2009). Coptis extracts enhance the anticancer effect of estrogen receptor antagonists on human breast cancer cells. Biochem. Biophys. Res. Commun. 378, 174-178.

Lohrmann, E., Burhoff, I., Nitschke, R. B., Lang, H. J., Mania, D., Englert, H. C., Hropot, M., Warth, R., Rohm, W., Bleich, M., and Greger, R. (1995). A new class of inhibitors of cAMP-mediated Clsecretion in rabbit colon acting by the reduction of cAMP-activated K+ conductance. Pflügers Arch. 429, 517-530.

Ma, T., Thiagarajah, J. R., Yang, H., Sonawane, N. D., Folli, C., Galietta, L. J., and Verkman, A. S. (2002). Thiazolidinone CFTR inhibitor identified by high-throughput screening blocks cholera toxin-induced intestinal fluid secretion. J. Clin. Invest. 110, 1651-1658.

Mantena, S. K., Sharma, S. D., and Katiyar, S. K. (2006). Berberine inhibits growth, induces G1 arrest and apoptosis in human epidermoid carcinoma A431 cells by regulating Cdki-Cdk-cyclin cascade, disruption of mitochondrial membrane potential and cleavage of caspase 3 and PARP. Carcinogenesis 27, 2018-2027.

Matthews, J. B., Awtrey, C. S., Hecht, G., Tally, K. J., Thompson, R. S., and Madara, J. L. (1993). Phorbol ester sequentially downregulates cAMP-regulated basolateral and apical Cl- transport pathways in T84 cells. Am. J. Physiol. Cell Physiol. 265, C1109-C1117.

McConnachie, G., Langeberg, L. K., and Scott, J. D. (2006). AKAP signaling complexes: getting to the heart of the matter. Trends Mol. Med. 12, 317-323.

Mun, E. C., Mayol, J. M., Reegler, M., O’Brien, T. C., Farokhzad, O. C., Song, J. C., Pothoulakis, C., Hrnjez, B. J., and Matthews, J. B. (1998). Levamisole inhibits intestinal Clsecretion via basolateral $\mathrm{K}+$ channel blockade. Gastroenterology 114, 1257-1267.

O’Mahony, F., Alzamora, R., Betts, V., LaPaix, F., Carter, D., Irnaten, M., and Harvey, B. J. (2007). Female gender-specific inhibition of KCNQ1 channels and chloride secretion by 17 -beta estradiol in rat distal colonic crypts. J. Biol. Chem. 282, 24563-24573.

O’Mahony, F., Alzamora, R., Chung, H. L., Thomas, W., and Harvey, B. J. (2009). Genomic priming of the antisecretory response to estrogen in rat distal colon throughout the estrous cycle. Mol. Endocrinol. 23, 1885-1899.

Pan, G. Y., Wang, G. J., Liu, X. D., Fawcett, J. P., and Xie, Y. Y. (2002). The involvement of P-glycoprotein in berberine absorption. Pharmacol. Toxicol. 91, 193-197.

Preston, P., Wartosch, L., Günzel, D., Fromm, M., Kongsuphol, P., Ousingsawat, J., Kunzelmann, K., Barhanin, J., Warth, R., and Jentsch, T. J. (2010). Disruption of the $\mathrm{K}+$ channel betasubunit KCNE3 reveals an important role in intestinal and tracheal Cl- transport. J. Biol. Chem. 285, 7165-7175.

Rabbani, G. H., Butler, T., Knight, J., Sanyal, S. C., and Alam, K. (1987). Randomized controlled trial of berberine sulfate therapy for diarrhea due to enterotoxigenic Escherichia coli and Vibrio cholerae. J. Infect. Dis. 155, 979-984.

Reenstra, W. W. (1993). Inhibition of cAMP- and Ca2+-dependent Clsecretion by phorbol esters: inhibition of basolateral $\mathrm{K}+$ channels. Am. J. Physiol. Cell Physiol. 264, C161-C168.

Robbins, J. (2001). KCNQ potassium channels: physiology, pathophysiology, and pharmacology. Pharmacol. Ther. 90, 1-19.

Rufo, P. A., Merlin, D., Riegler, M., Ferguson-Maltzman, M. H., Dickinson, B. L., Brugnara, C., Alper, S. L., and Lencer, W. I. (1997). The antifungal antibiotic, clotrimazole, inhibits chloride secretion by human intestinal T84 cells via blockade of distinct basolateral $\mathrm{K}+$ conductances. Demonstration of efficacy in intact rabbit colon and an in vivo mouse model of cholera. J. Clin. Invest. 100, 3111-3120.

Schroeder, B. C., Waldegger, S., Fehr, S., Bleich, M., Warth, R., Greger, R., and Jentsch, T. J. (2000). A constitutively open potassium channel formed by KCNQ1 and KCNE3. Nature 403, 196-199.

Schultheiss, D., and Diener, M. (1998). $\mathrm{K}+$ and $\mathrm{Cl}-$ conductances in the distal colon of the rat. Gen. Pharmacol. 31, 337-342.

Tai, Y. H., Feser, J. F., Marnane, W. G., and Desjeux, J. F. (1981). Antisecretory effects of berberine in rat ileum. Am. J. Physiol. Gastrointest. Liver Physiol. 241, G253-G258.

Tang, W., and Eisenbrand, G. (1992). Chinese Drugs of Plant Origin: Chemistry, Pharmacology, and Use in Traditional and Modern Medicine. Berlin: Springer-Verlag Press, 361-371.
Tasken, K., and Aandahl, E. M. (2004). Localized effects of cAMP mediated by distinct routes of protein kinase A. Physiol. Rev. 84, 137-167.

Taylor, C. E., and Greenough, W. B. (1989). Control of diarrheal diseases. Annu. Rev. Public Health 10, 221-244.

Taylor, C. T., and Baird, A. W. (1995). Berberine inhibition of electrogenic ion transport in rat colon. $\mathrm{Br}$. J. Pharmacol. 116, 2667-2672.

Taylor, C. T., Winter, D. C., Skelly, M. M., O’Donoghue, D. P., O'Sullivan, G. C., Harvey, B. J., and Baird, A. W. (1999). Berberine inhibits ion transport in human colonic epithelia. Eur. J. Pharmacol. 368, 111-118.

Warth, R., Hamm, K., Bleich, M., Kunzelmann, K., von Hahn, T., Schreiber, R., Ullrich, E., Mengel, M., Trautmann, N., Kindle, P., Schwab, A. and Greger, R. (1999). Molecular and functional characterization of the small $\mathrm{Ca} 2+$-regulated $\mathrm{K}+$ channel (rSK4) of colonic crypts. Pflügers Arch. 438, 437-444.

Yamamoto, K., Takase, H., Abe, K., Sato, Y., and Suzuki, A. (1993). Pharmacological studies on anti-diarrhoeal effects of a preparation containing berberine and geranii herba. Nippon Yakurigaku Zasshi 101, 169-175.

Yu, C., Chai, X., Yu, L., Chen, S., and Zeng, S. J. (2011). Identification of novel pregnane $\mathrm{X}$ receptor activators from traditional Chinese medicines. J. Ethnopharmacol. 136, 137-143.

Conflict of Interest Statement: The authors declare that the research was conducted in the absence of any commercial or financial relationships that could be construed as a potential conflict of interest.

Received: 13 May 2011; paper pending published:04 June 2011; accepted: 18 June 2011; published online: 30 June 2011.

Citation: Alzamora R, O'Mahony F, Ko $W-H$, Yip $T W-N$, Carter D, Irnaten $M$ and Harvey BJ (2011) Berberine reduces cAMP-induced chloride secretion in T84 human colonic carcinoma cells through inhibition of basolateral KCNQ1 channels. Front. Physio. 2:33. doi: 10.3389/fphys.2011.00033

This article was submitted to Frontiers in Membrane Physiology and Biophysics, a specialty of Frontiers in Physiology. Copyright () 2011 Alzamora, O'Mahony, Ko, Yip, Carter, Irnaten and Harvey. This is an open-access article subject to a nonexclusive license between the authors and Frontiers Media SA, which permits use, distribution and reproduction in other forums, provided the original authors and source are credited and other Frontiers conditions are complied with. 